\title{
Assessment of Trace Elements and Human Health Risk Present in Wines Obtained in the Region of Dealurile Munteniei and Dealurile Moldovei Vineyards
}

\author{
Florin Dumitru BORA ${ }^{1}$, Anamaria CĂLUGĂR ${ }^{2}$, Claudiu Ioan BUNEA ${ }^{2,4^{*}}$, Ionut RACZ ${ }^{3}$ \\ ${ }^{1}$ Department of Physical-Chemistry and Biochemistry, Research Station for Viticulture and Enology \\ Târgu Bujoru, Romania \\ ${ }^{2}$ Department of Horticulture and Landscaping, University of Agricultural Sciences and Veterinary \\ Medicine, Cluj-Napoca, Romania \\ ${ }^{3}$ Wheat Breeding Department, Agricultural Research and Development Station Turda, Cluj-Napoca, \\ Romania \\ ${ }^{4}$ Department of Horticulture and Landscaping, Horticultural Research Station, Cluj-Napoca, Romania. \\ "corresponding author: claus_bunea@yahoo.com
}

BulletinUASVM Horticulture 76(2) / 2019

Print ISSN 1843-5254, Electronic ISSN 1843-5394

DOI:10.15835/buasvmcn-hort: 2019.0006

\begin{abstract}
The primary objectives of this research were to determine the concentration of some inorganic trace components, to evaluate the concentration levels of these in Romanian wines by daily consumption of wine and the health risk of inorganic trace components intake at these rates form Romanian wine. The results indicated that the concentration levels of inorganic components in red wine decreased in the order $\mathrm{Zn}>\mathrm{Mn}>\mathrm{Cr}>\mathrm{Cu}>\mathrm{Ni}>\mathrm{Pb}>\mathrm{Co}>\mathrm{Cd}$, in case of white wine decreased in the order $\mathrm{Zn}>\mathrm{Mn}>\mathrm{Cu}>\mathrm{Cr}>\mathrm{Ni}>\mathrm{Pb}>\mathrm{Co}>\mathrm{Cd}$. Based on a 60-kilogram adult person, and moderate consumption of 200 milliliters of wine/day, the estimated daily intake of these inorganic components from wines was well below the daily allowance. The target hazard quotient suggests that the exposed humans would not experience significant health risks when ingesting these individual elements from daily consumption of 200 milliliters of Romanian wines/day.
\end{abstract}

Keywords: estimated daily intake, health risk assessment, ICP-MS, multi-element analysis, Romanian wine

\section{Introduction}

Without doubt, the determination of metals in different type of food samples is of high importance for several reasons, the most important one being the nutritional, as well as toxic effects of these elements or their compounds (Płotka-Wasylka et al., 2018). Knowledge of the content of metals in alcoholic drinks such as wine is also very important. In many countries, alcoholic beverages, including wine, constitute more than $12 \%$ of the general consumption of beverages (Goldberg and Bromberg, 1996). Therefore, they could be an important source of several metal ions. Monitoring of certain elements in wines by oenological laboratories needs special attention due to their toxic effect on the human body, some metals must be kept under control according to the International Organization of Vine and Wine (O.I.V.) regulations.

The mineral concentration of wine is influenced by many factors. The majority part of the total metal concentration from wine is of natural origin (Kunkee and Eschnauer, 2003, Kment et al., 2005, Pohl, 2007) and reflects the geochemistry 
of vineyard soil on which vines are grown. The concentrations of these metals are characteristic and influenced by the type of soil, maturity of the grapes, their variety, and the climatic conditions during their growth (Pohl, 2007). The contribution of metals of a secondary origin is associated with an external concentration on the vine during growth or during the different stages in winemaking, from harvesting to bottling and cellaring (Fiket et al., 2011). During the growth of grapes in a vineyard, contaminations can be classified as geogenic (originating in the vineyard soil), originating from fertilizing and plant protection practices, or from environmental pollution (Pohl, 2007). Application of fungicides, pesticides and fertilizers containing $\mathrm{Pb}, \mathrm{Cd}, \mathrm{As}, \mathrm{Mn}, \mathrm{Cu}$ and $\mathrm{Zn}$ compounds leads to accumulation of these elements in vineyard soil, grapes and wine (Galani-Nikolakaki et al., 2002, Lara et al., 2005, Cvetković et al., 2006, Álvarez et al., 2007). Finally, there is an enological source of metals, as contamination may occur at different steps of wine production. The reason for this is the long contact of wine with materials from which winemaking machinery, pipes, barrels and casks used for handling and storing of wine are made from aluminum, stainless steel, wood, brass and glass. This is the usual source of $\mathrm{Fe}, \mathrm{Cu}, \mathrm{Cr}, \mathrm{Cd}, \mathrm{Al}$ and Zn (Kment et al., 2005, Lara et al., 2005, Pohl, 2007).

Also, we must monitor permanently the metal content in wine for authenticity purposes as well as quality control (Fabani et al., 2010, Kostić et al., 2010). The elements can influence the winemaking process or change its taste and quality. A typical example can be $\mathrm{Fe}$, which may have a strong influence on wine evolution during the fermentation process. In fact, the importance of its impact may vary due to several reasons, e.g. the coloring agents absence/presence, the ventilation of the ferments level, the extent to which this element interacts with the yeast, and the aliquots father which at the end of the process it is eliminated along with sediments (Płotka-Wasylka et al., 2018). $\mathrm{Cu}$ is also an important micronutrient, but at the same time, when consumed in excess, it is potentially toxic for humans (Pyrzyńska, 2007). Several elements, including $\mathrm{Cu}, \mathrm{Fe}, \mathrm{Al}$, and $\mathrm{Zn}$, contribute to haze formation and taste effects (Riganakos and Veltsistas, 2003). Monitoring and determination of other elements, e.g. $\mathrm{Pb}, \mathrm{As}$ and $\mathrm{Cd}$ is also of high importance due to their potential toxic effects on the human body (Elci et al., 2009, Monasterio and Wuilloud, 2009). Besides, some metals content can be applied to identify its origin due to the direct relationship with soil composition (Greenough et al., 2005).

Although moderate consumption of wine has proven to be very useful for human health, through the intake of a multitude of nutrients, as vitamins, mineral elements, amino acids, and polyphenols (Goldberg et al., 2001, Martin et al., 2017). There is an acute lack of assessment of the dangers of wine safety hazards concerning alcohol constraints. Around the world, but also in Romania, food security has always been an important point for the government. Agricultural Organization of the United Nations (FAO)/ World Health Organization (WHO) Expert Committee on Food Additives (JECFA) reports the tolerance limits of certain pollutants for human consumption. $\mathrm{Pb}$ is a prevalent toxic component that impacts humans hematological, nervous, and reproductive systems, causing pathological alterations in organs, resulting in a decreased intelligent quotient (IQ) for children (Needleman, 2004). Cd is not an essential component for the human body, it is toxic to kidneys, bones and cardiovascular system also (Fang et al., 2014) and the provisional tolerable monthly intake (PTMI) is $25.5 \mu \mathrm{g} / \mathrm{kg}$ body weight of Cd (FAO/WHO, 2011). $\mathrm{Cr}$ is an essential structure of the human body, depending on its valence state, it can also harm the human body. Trivalent $\mathrm{Cr}$ ( $\mathrm{Cr}$ (III)) is a useful factor, but the toxicity of hexavalent $\mathrm{Cr}(\mathrm{Cr}(\mathrm{VI}))$ is very toxic to the human body (Tuzen, 2009). $\mathrm{Ni}$ is not an essential component for the human body, it can cause negative lung impacts, while carbonyl nickel has acute toxicity and carcinogenicity (Forti et al., 2011) and the provisional tolerable daily intake (PTDI) of Ni-based on lowest observed adverse effect level (LOAEL) is $12.00 \mu \mathrm{g} / \mathrm{kg}$ body weight (WHO, 2005).

The contaminants presented above, especially inorganic trace components, were also determined in previous researches on winesamples (Koreňovká and Suhaj, 2005). Although poisoning induced by consumed wine was not confirmed, these contaminants are harmful to the human body due to their chronic and long-lasting effects. Besides, some useful minerals from wine such as $\mathrm{Mg}$, Co, $\mathrm{Cu}, \mathrm{Zn}, \mathrm{Al}$, and Se can cause negative reactions if their consumption exceeds certain concentrations. 
For example, Mo is a useful element for the human body, but the high levels of concentration in this mineral have a serious negative effect on the seminal material quality (Meeker et al., 2008). The provisional maximum tolerable daily intake of $\mathrm{Zn}$ is $1.00 \mathrm{mg} / \mathrm{kg}$ body weight (FAO/WHO, 1982) and the PTWI of Al is $1000 \mu \mathrm{g} / \mathrm{kg}$ body weight (FAO/ WHO, 2007). Compared to other ways, such as dermal contact, the consumption of some drinks or food, including inhalation, is a major source of human exposure of trace elements (Zhi-Hao et al., 2019), consideration should be given to the intake of these minerals through regular consumption of wine.

To this date, only several papers were published on trace element content of Romanian wines presenting data for a rather limited number of elements (Dehelean and Voica, 2012, Geana et al., 2013, Avram et al., 2014, Geana et al., 2016, Bora et al., 2018a). Concentration levels of $\mathrm{Cr}$, $\mathrm{Cu}, \mathrm{Fe}, \mathrm{Mn}$ and $\mathrm{Zn}$ in wine samples from the south-east of Romania were investigated by Bora et al. (2018a). Knowledge of the health risks associated with the ingestion of these elements from wine is insufficient. On the other hand, several agencies and organizations such as the US Environmental Protection Agency (US EPA) and JECFA have provided clear guidelines on the intake elements via food or drink by people. Based on these considerations, it is necessary to assess the health risk of Romanian wine from different wine production areas. The main objectives of the present study were: (1) the establishment and validation of an analytical method for the determination of trace elements in wines using ICP-MS (inductively coupled plasma mass spectrometry) after microwave-assisted digestion; (2) to determine the total concentration of $\mathrm{Pb}, \mathrm{Cd}$, $\mathrm{Ni}, \mathrm{Co}, \mathrm{Zn}, \mathrm{Cr}, \mathrm{Cu}$ and $\mathrm{Mn}$ from wines and grape juice obtained from five different wine-growing areas of Romania; (3) comparing the concentration from different wine areas to the results reported in the previous literature and to analyze the distribution characteristics of this trace element in Romanian wines and grape juice samples; and (4) also to the estimation of the ingestion rates of some elements from Romanian wines by daily consumption of wine as well as the health risk caused by the intake of these elements.

\section{Materials and methods}

\section{Study area}

A total of 321 wines and grape juice samples (174 red wines and 147 white wines) were analyzed in this research. All samples (wines and grape juice) used were formed from the 2011-2016 vintage. Wines and grape juice samples were collected from five different vineyards areas: Nicoreşti, Ivești, Panciu, Obobești, and Dealu Mare. The

Table 1. Wine, grape juice and production area

\begin{tabular}{ccll}
\hline No. & Type & \multicolumn{1}{c}{ Variety } & Area of production \\
\hline 1. & Red & Babeasca neagra & Nicorești; Ivești; Panciu \\
\hline 2. & Red & Cabernet Sauvignon & Nicorești; Ivești; Panciu; Dealu Mare \\
\hline 3. & Red & Feteasca neagra & Nicorești; Ivești; Dealu Mare \\
\hline 4. & Red & Merlot & Panciu; Obobești; Dealu Mare \\
\hline 5. & Red & Pinot Noir & Dealu Mare \\
\hline 6. & Red & Burgund Mare & Dealu Mare \\
\hline 7. & White & Feteasca regala & Nicorești; Ivești; Panciu \\
\hline 8. & White & Aligoté & Nicorești; Ivești; Panciu \\
\hline 9. & White & Rkatiteli & Nicorești; Ivești \\
\hline 10. & White & Italian Riesling & Panciu; Obobești \\
\hline 11. & White & Muscat Ottonel & Panciu \\
\hline 12. & White & Sauvignon blanc & Nicorești; Ivești; Panciu; Obobești; Dealu Mare \\
\hline 13 & White & Pinot Gris & Dealu Mare \\
\hline 14. & White & Tamaioasa Romaneasca & Dealu Mare \\
\hline 15. & White & Busuioaca de Bohotin & Dealu Mare \\
\hline & & &
\end{tabular}


wines and grape juice samples under this study and production areas are presented in (Tab. 1).

\section{Sample collection and micro vinification process}

Grape samples (15 kg/cultivar) were collected for each cultivar from 10-15 vines. The grapes were placed in the lower third, middle and top of each vine and grapes were exposed to shade and sun (Bora et al., 2015). In this way a better homogenization of the grape samples can be achieved. The grape juice (must) samples were obtained by using the manual press. The wine samples resulted from micro-vine production. Micro-vine production was done according to the methodology described by Bora et al. (2016). All wines were provided from the wineries as finished wines in $750 \mathrm{~mL}$ glass bottles with cork stoppers and were stored at 3-4 ${ }^{\circ} \mathrm{C}$ before analysis. One bottle was used for each sample, and three replicates were taken. All vines were planted since 1979 , and the vine plantation was organized with $2.2 \times 1 \mathrm{~m}$ distance between rows and plants. Vines were pruned according to the Guyot system and were grown on speliers.

\section{Sample preparation}

To remove the appreciable amounts of deposits and colloidal suspensions present, the samples werefiltrated (cellulose acetate membrane $0.45 \mu \mathrm{m}$ pore size) and then acid-digested in a microwave oven (STARD D Microwave Digestion System, Milestone). To determine the trace elements from wine and grape juice were used an amount of 0.5 $\mathrm{mL}$ (sample) and adjusted $8 \mathrm{~mL}\left(7 \mathrm{ml} \mathrm{HNO} \mathrm{H}_{3} 65 \%\right.$ $+1 \mathrm{~mL} \mathrm{H}_{2} \mathrm{O}_{2}$ ). The operation conditions for the applied microwave digestion system are given in (Tab. 2).

\section{Reagents and solutions}

Eight elements $\mathrm{Pb}, \mathrm{Cd}, \mathrm{Co}, \mathrm{Ni}, \mathrm{Cr}, \mathrm{Zn}, \mathrm{Mn}$, and $\mathrm{Cu}$ ) were analyzed to estimate the dietary intake rates of these elements from Romanian wines by daily wine consumption as well as the health risk caused by their intake. The calibration was performed using XXICertiPUR multielement standard. The working standards and the control sample were prepared daily from the intermediate standards that were prepared from the stock solution. The intermediate solutions stored in polyethylene bottles and glassware was cleaned by soaking in $10 \% \mathrm{HNO}_{3}$ for 24 hours and rinsing

Table 2. Microwave digestion operating programmer

\begin{tabular}{cccccc}
\hline Step & $\begin{array}{c}\text { Initial temperature } \\
\mathbf{( \circ} \mathbf{C})\end{array}$ & $\begin{array}{c}\text { Final temperature } \\
(\mathbf{o} \mathbf{C})\end{array}$ & $\begin{array}{c}\text { Ramping time } \\
\mathbf{( o} \mathbf{C})\end{array}$ & $\begin{array}{c}\text { Time holds } \\
(\mathbf{m i n})\end{array}$ & Power (W) \\
\hline 1 & 25 & 100 & 15 & 10 & $800(75 \%)$ \\
\hline 2 & 100 & 150 & 10 & 5 & $800(100 \%)$ \\
\hline 3 & 150 & 200 & 10 & 10 & $1600(85 \%)$ \\
\hline
\end{tabular}

Table 3. ICP-MS the conditions under which the analyses were carried out

\begin{tabular}{ccccc}
\hline Element & Calibration coefficient & LoD $^{\mathbf{1}}(\boldsymbol{\mu g} / \mathbf{L})$ & LoQ $^{\mathbf{2}}(\boldsymbol{\mu g} / \mathbf{L})$ & BEC $^{\mathbf{3}}(\boldsymbol{\mu g} / \mathbf{L})$ \\
\hline $\mathrm{Pb}$ & 0.9999 & 0.013 & 0.028 & 0.019 \\
\hline $\mathrm{Cd}$ & 0.9999 & 0.0056 & 0.018 & 0.088 \\
\hline $\mathrm{Ni}$ & 0.9999 & 0.0016 & 0.0039 & 0.0031 \\
\hline $\mathrm{Co}$ & 0.9999 & 0.00019 & 0.0006 & 0.00038 \\
\hline $\mathrm{Zn}$ & 0.9999 & 0.0019 & 0.0052 & 0.0018 \\
\hline $\mathrm{Cr}$ & 0.9999 & 0.0059 & 0.018 & 0.0053 \\
\hline $\mathrm{Cu}$ & 0.9999 & 0.026 & 0.084 & 0.051 \\
\hline $\mathrm{Mn}$ & 0.9999 & 0.036 & 0.0109 & 0.0058 \\
\hline
\end{tabular}

$\mathrm{LoD}^{1}=$ detection limit; $\mathrm{LoQ}^{2}=$ quantification limits; $\mathrm{BEC}^{3}=$ background equivalent concentration . 
at least ten times with ultrapure water (Milli-Q Integral ultrapure water-Type 1). The accuracy of the methods was evaluated by replicate analyses of known concentration samples (between $10 \mu \mathrm{L}$ to $10 \mathrm{~mL}$ concentrations) and obtained values ranged between 0.8-13.1\% (Bora et al., 2018a).

For quality control, blank and triplicate samples $(n=3)$ were analyzed during the procedure. The variation coefficient was under $5 \% \%$ and detection limits (ppb) were determined by the calibration curve method. Limit of detection (LoD) and Limit of quantification (LoQ) were calculated according to the mathematical formulas: $\mathrm{LoD}=$ $3 \mathrm{SD} / \mathrm{s}$ and $\mathrm{LoD}=10 \mathrm{SD} / \mathrm{s}$ (SD = standard deviation; $\mathrm{s}=$ slope of the calibration curve) (Tab. 3).

\section{ICP-MS Analysis}

Elemental analysis was performed with an iCAP Q (Thermo Scientific, Waltham, MA, USA) $\mathrm{X}$-Series II inductively coupled plasma mass spectrometer. The instrument is equipped with a quartz torch with a Plasma Screen device, a quadrupole mass analyzer, lens ion optics based on a hexapole design with a chicane ion deflector and a simultaneous detector with real-time multichannel analyzer electronics, operating in either an analog signal or pulse counting mode. A high-efficiency ESI APEX-Q nebulizer (Epond SA, Vevey, Switzerland) was used as a nebulization system. The instrument and accessories were PC-controlled by Qtegra software. All relevant instrumental conditions are given in (Tab. 4). The isotopes used were ${ }^{53} \mathrm{Cr},{ }^{55} \mathrm{Mn},{ }^{59} \mathrm{Co},{ }^{60} \mathrm{Ni}$, ${ }^{63} \mathrm{Cu},{ }^{66} \mathrm{Zn},{ }^{114} \mathrm{Cd},{ }^{206} \mathrm{~Pb} /{ }^{207} \mathrm{~Pb} /{ }^{208} \mathrm{~Pb}$. A stability test was performed before each analysis session by monitoring ${ }^{7} \mathrm{Li},{ }^{59} \mathrm{Co},{ }^{115} \mathrm{In},{ }^{140} \mathrm{Ce}$, and ${ }^{238} \mathrm{U}$ masses and making sure precision was better than $2 \%$ : instrumental precision was under $2 \%$ for the trace elements, while the overall uncertainty (involving both instrumental analysis and sample preparation), calculated on the basis of five genuine replicates, was better than $5 \%$.

Instrumental drift where corrected using rhodium as an internal standard, at concentration level of $10 \mu \mathrm{g} / \mathrm{L}$, added to both calibration standards and wine samples, to normalize the instrument response Rhodium was selected as an internal standard due to very low background signal found for this element, and because it was not present in the wine samples (Ivanova-Petropulos et al.,

Table 4. ICP-MS operating conditions

\begin{tabular}{lc}
\hline \multicolumn{1}{c}{ Instrument } & $\begin{array}{c}\text { iCAP Q } \\
\text { (ICP-MS Thermo Scientific) }\end{array}$ \\
\hline Sampler cone & Ni (standard) \\
\hline Skimmer cone & Ni (standard) \\
\hline Nebulizer & Quartz, $2.5 \mathrm{~mm}$ (standard) \\
\hline Plasma torch & \\
\hline Integration time & $0.3 \mathrm{~s} \times 1$ point \\
\hline Cd & $0.1 \mathrm{~s} \times 1$ point \\
\hline All other & 1 \\
\hline Replicates & $1500 \mathrm{~W}$ \\
\hline Tune parameters & $7.6 \mathrm{~mm}$ \\
\hline RF & $1.00 \mathrm{~L} / \mathrm{min}$ \\
\hline Sample depth & $0.25 \mathrm{~L} / \mathrm{min}$ \\
\hline Carrier gas & $+6 \mathrm{~V}$ \\
\hline Makeup gas & $-145 \mathrm{~V}$ \\
\hline Extract 1 & $3 \mathrm{~V}$ \\
\hline Extract 2 & $3.5 \mathrm{~mL} / \mathrm{min}$ \\
\hline Energy discrimination & $0.65 \%$ \\
\hline Reaction gas He & $2.08 \%$ \\
\hline CeO ${ }^{+} /$Ce ${ }^{+}$ & \\
\hline Ce ${ }^{++} /$Ce &
\end{tabular}


2016). The addition of the internal standard to the wine samples was performed by the peristaltic pump.

A synthetic wine sample (Titrivin), $12 \%$ ethanol, $4 \mathrm{~g} / \mathrm{L}$ tartaric acid and $\mathrm{pH} 3.4$ was prepared to contain the solution to give rise to multiple interferences across a spectrum range of common analytes and test the capacity of He collision mode to remove all overlapping polyatomic species. Two sets of spectra have been obtained that demonstrate the capacity of the He collision mode to remove multiple interferences: one in" no gase" mode and the other with He added to the cell. Data correction or background correction was applied in $\mathrm{He}$ mode for the elements $\mathrm{Pb}, \mathrm{Cd}, \mathrm{Ni}, \mathrm{Co}, \mathrm{Zn}, \mathrm{Cr}$, $\mathrm{Cu}$, and $\mathrm{Mn}$.

\section{Statistical Analysis and Calculations}

All analyses were performed three times, the mean values of three duplicates were used as the result of each wine and must sample, statistical significance was calculated at $95 \%$ confidence limit using Duncan's multiple ranges $(p<0.05)$ with the help of SPSS 24.0 software for Windows (SPSS Inc., Chicago, IL, USA) software. The boxplot was created by Microsoft Office 2019 professional plus for Windows and Sigma plot 10.0.

The estimated daily intake (EDI, $\mu \mathrm{g} / \mathrm{kg} \mathrm{bw} /$ day) of trace elements from wine relied on the concentration of the elements in the wine, the daily intake rate of wine consumers and the bodyweight (USEPA, 1989, Zhi-Hao et al., 2019) and it was calculated by the formula:

$$
\mathrm{EDI}=(\mathrm{C} \times \mathrm{R}) / \mathrm{BW}
$$

where $\mathrm{C}$ - the concentration of a single element in the wine, $\mu \mathrm{g} / \mathrm{L} ; \mathrm{R}$ - the daily rate of intake for adult wine drinkers, L/day; BW - the average body weight of the population evaluated, $\mathrm{kg}$ (Zhi-Hao et al., 2019).

Based on the target hazard quotient (THQ) was calculated health risk due to the consumption of wine, from the ration EDI and an oral reference dose (USEPA, 1989, Zhi-Hao et al., 2019).

$$
\mathrm{THQ}=\mathrm{EDI} / \mathrm{RfD}
$$

where RfD - the oral reference dose for each element, $\mu \mathrm{g} / \mathrm{kg}$ bw/day.
If the THQ is less than 1, it means that there are no obvious adverse effects on the intake of these elements from wine. If the THQ is equal to or above 1 , there is a danger to humans heath (Zhi-Hao et al., 2019). The total THQ values of the elements evaluated in wine are described as the hazard index (HI) used to evaluate the comprehensive health risks of wine.

\section{Results and discussions}

The results of the measurement of $\mathrm{Pb}, \mathrm{Cd}, \mathrm{Ni}$, $\mathrm{Co}, \mathrm{Zn}, \mathrm{Cr}, \mathrm{Cu}$ and $\mathrm{Mn}$ in wine samples are shown in (Tab. 5-7) according to the type of wine, region and winemaker. The majority of elements were found at part per billion (ppb) levels so all values are reported as $\mu \mathrm{g} / \mathrm{L}$. In Table 5 data for maximum permissible limit (M.P.L.) of toxic elements in wine are defined as wine standards given by the Office International de la Vigne et du Vin (O.I.V., 2016).

$\mathrm{Zn}$ had the highest concentration levels indifferent the sample of wine analyzed (2524.69 $\mu \mathrm{g} / \mathrm{L})$ and $\mathrm{Mn}(1346.76 \mu \mathrm{g} / \mathrm{L})$, and $\mathrm{Pb}$ recorded the smallest average concentration $\mathrm{Pb}(12.86$ $\mu \mathrm{g} / \mathrm{L})$ and $\mathrm{Cd}(0.12 \mu \mathrm{g} / \mathrm{L})$, other elements concentration declined in the order $\mathrm{Cr}>\mathrm{Cu}>\mathrm{Co}$ $>\mathrm{Ni}$. The concentration of metals analyzed varied in all wine were as follows: $\mathrm{Pb}(12.86-78.36), \mathrm{Cd}$ (0.12-0.79), Ni (88.45-382.39), Co (1.48-11.38), Zn (480.56-2524.69), Cr (215.18-838.87), Cu (215.37-638.53), Mn (336.85-1346.76).

If relative abundances of the elements in red wines are compared, the tendency at the ranking is as follows: $\mathrm{Zn}>\mathrm{Mn}>\mathrm{Cr}>\mathrm{Cu}>\mathrm{Ni}>\mathrm{Pb}>\mathrm{Co}$ $>\mathrm{Cd}$. Comparison of the relative abundances of the essential elements in white wines reveals the following tendency: $\mathrm{Zn}>\mathrm{Mn}>\mathrm{Cu}>\mathrm{Cr}>\mathrm{Ni}>\mathrm{Pb}$ $>\mathrm{Co}>\mathrm{Cd}$. The order of the content of elements in wines is similar to the one reported by Bora et al. (2018a), Bora et al. (2018b), Geana et al. (2016) and approximately corresponds to the general order of the content of elements in plants (Kabata-Pendias and Pedias, 1984). This ranking is not to be taken as exact because there are many variables in wine production, such as regions, soil, and climate. For this reason, the amount of an element may be found in a wide variety of ranges for different wines even if they are produced from the same type of grapes. For example, $\mathrm{Zn}$ was found to be between $328.77 \mu \mathrm{g} / \mathrm{L}$ and 1959.85 $\mu \mathrm{g} / \mathrm{L}$ in Cabernet Sauvignon red wines which is quite a wide range. 
Some of the investigation elements $(\mathrm{Pb}, \mathrm{Cd}$, and $\mathrm{Co}$ ) are present in analyzed wines in a very narrow range, whereas for other elements $(\mathrm{Ni}, \mathrm{Zn}, \mathrm{Cr}, \mathrm{Cu}$, and $\mathrm{Mn}$ ) variations are much greater. For most of the analyzed elements, the obtained concentration falls into concentration ranges for Romanian wines by Avram et al. (2014), Dinca et al. (2016), Geana et al. (2016) and Bora et al. (2018a), Bora et al. (2018b). Only the $\mathrm{Zn}$ content of the studied wines is higher than $\mathrm{Zn}$ concentrations reported by Dinca et al. (2016), Geana et al. (2016), whereas the levels of $\mathrm{Mn}$ and $\mathrm{Cr}$ are found to be lower than those reported by Dinca et al. (2016), Geana et al. (2016). The measured concentrations are also consistent for most of the elements with findings of Kment et al. (2005) for Czech wines, Álvarez et al. (2007) for Spanish wines and Interesse et al. (1994) for Italian wines. Fiket et al. (2011) reported higher values of $\mathrm{Cu}$ and $\mathrm{Pb}$ comparing to analyzed Romanian wines. The concentration levels of $\mathrm{Cd}$, Co and Mn are lower than those reported for Slovenia and Istria wines by Fiket et al. (2011). These differences can be explained by variations in vineyard soil geochemistry and a higher degree of anthropogenic influence of Czech and Cretan wines. Kment et al. (2005) and Geana et al. (2013) found $\mathrm{Pb}$ in higher concentrations in Czech and Romanian wines, which can be explained solely by differences in soil geochemistry.

Due to the significantly high concentration of $\mathrm{Ni}, \mathrm{Zn}, \mathrm{Cr}$, and $\mathrm{Cu}$ in the analyzed wine samples a prediction can be made: these elements may be dissolved in the wine during the production steps in metal vessels (Preedy and Watson, 2003, Guardia and Garrigues, 2015). It sounds probable considering the acidic nature of the wine. Table 6 features the observed concentration ranges and the average of each element, according to different winemakers, to render an opportunity to compare the possible differences emerging from the wines. In terms of $\mathrm{Cd}$ distribution, it can be seen that this element records comparative concentrations in all the studied vines, except Odobesti vineyard, and its average concentration $(0.83 \mu \mathrm{g} / \mathrm{L})$ was considerably greater compared to other wine regions.

$\mathrm{Pb}$ registered the highest concentrations in the Ivești (average $70.02 \mu \mathrm{g} / \mathrm{L}$ ) and Nicorești area (average $33.34 \mu \mathrm{g} / \mathrm{L}$ ) compared to other wine regions. Panciu area (average $324.93 \mu \mathrm{g} / \mathrm{L}$ ) and Nicorești area (average $324.29 \mu \mathrm{g} / \mathrm{L}$ ) have recorded the highest concentrations which were significantly higher than the Ivești (average $195.36 \mu \mathrm{g} / \mathrm{L}$ ) and Odobești area (average 210.43 $\mu \mathrm{g} / \mathrm{L}$ ) areas, in terms of $\mathrm{Ni}$ distribution. The Co, $\mathrm{Zn}$ and $\mathrm{Cu}$ levels have recorded significantly higher concentrations in Ivești (average 19.22 $\mu \mathrm{g} \mathrm{Co} / \mathrm{L}, 2652.74 \mu \mathrm{g} \mathrm{Zn/L}$ and $631.92 \mu \mathrm{g} \mathrm{Cu} / \mathrm{L}$ ) regions compared to other wine regions. The level concentration of $\mathrm{Cr}$ and $\mathrm{Mn}$ was the highest in the Nicorești (average 1032.19 $\mu \mathrm{g} \mathrm{Cr} / \mathrm{L}$ ) and Dealu Mare (average $489.32 \mu \mathrm{g} \mathrm{Mn/L)} \mathrm{respectively.}$ The results are given in (Tab. 6) shown that $\mathrm{Zn}$ amounts of Ivești and Panciu wines are relatively high which is also related to the type of wine, the mentioned wine is red.

World Health Organization (WHO) does not specify a maximum $\mathrm{Cd}$ in wine. But at this point, drinking water specifications are useful considering all other food samples. According to WHO, Cd concentration must be below $5.0 \mathrm{ppb}$ in drinking water (Rielly, 2002a,b). The outcome of this study reveals that the concentration of $\mathrm{Cd}$ to be below the allowed limit for every analyzed sample. In literature, comments have been made about the effects of thermal power plants on the accumulation of non-essential metals like $\mathrm{Cd}$ in similar studies (Bajpai et al., 2010, Kallithraka et al., 2001, Dragovin et al., 2013). However, such interpretation of our study would not support Kallithtraka's reasoning, since the concentration of $C d$ is very low. The $C d$ values were measured to be $0.79 \pm 0.09$ and $0.83 \pm 0.05 \mu \mathrm{g} / \mathrm{L}$ (Tab. 5 and 6 ) which are lowest that $5.0 \mu \mathrm{g} / \mathrm{L}$ (WHO) and much less so $10 \mu \mathrm{g} / \mathrm{L}$ (O.I.V., 2016).

Average value \pm standard deviation $(n=3)$. Roman letters represent the significance of the difference (Duncan test, $\mathrm{p}<0.05$ ). The difference between any two values, followed by at least one common letter, is insignificant. M.P.L = maximal permissible allowed (O.I.V., 2016). LOQ = lower than the limit of quantification.

These values are mostly encountered in the wines produced from grapes grown in a highly industrialized area, with a vast number of thermal plants. On the other hand, values reported by Kallithraka et al. (2001) are much higher leading to the notion that thermal power plants are not the only reason for contamination.

Observed $\mathrm{Pb}$ concentration is very much lower than those allowed by O.I.V. The highest values identified for $\mathrm{Pb}(78.36 \pm 2.62 \mu \mathrm{g} / \mathrm{L})$ are 


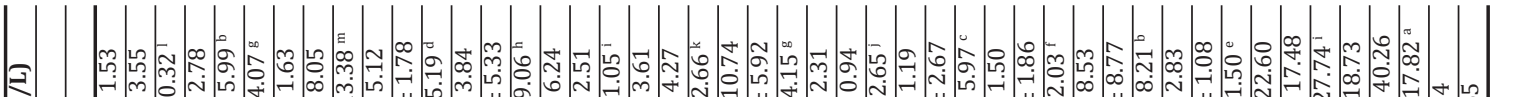
20

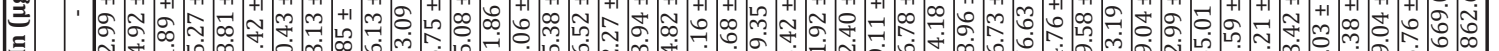
$\Sigma$

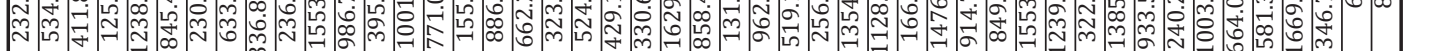

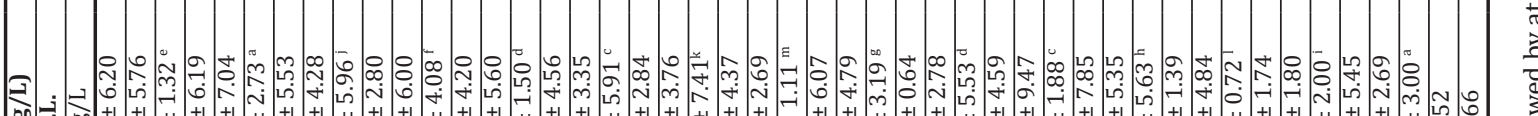

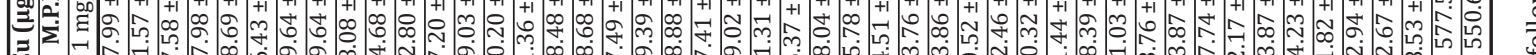

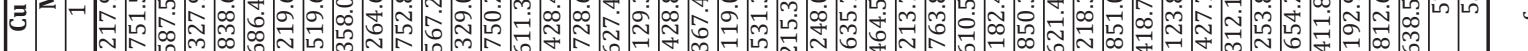

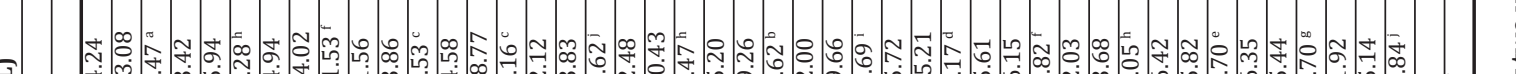

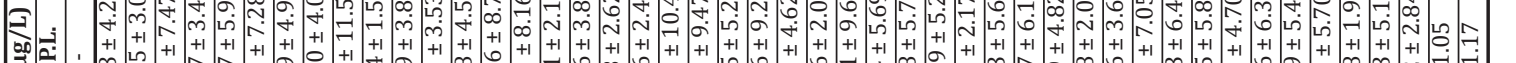

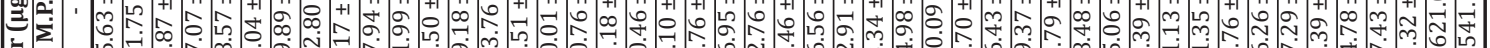

2
$n=0$

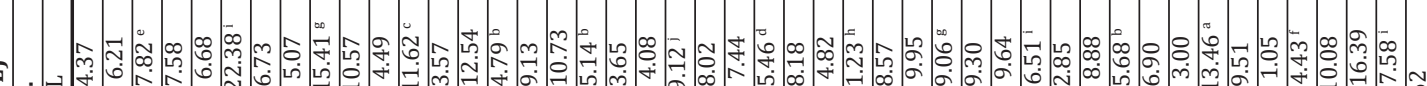

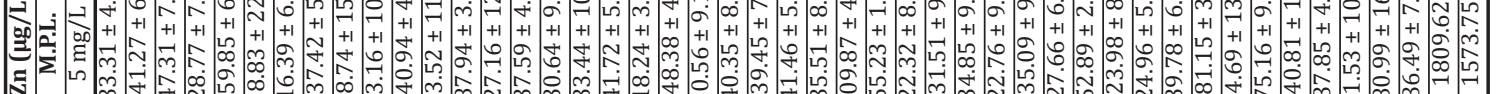

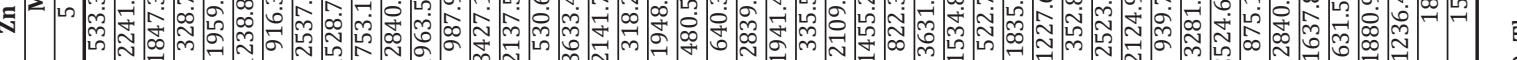

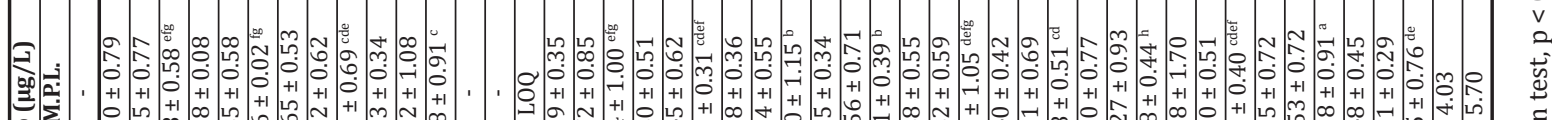

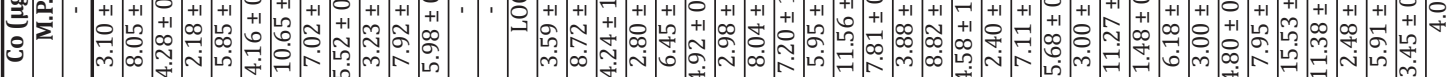

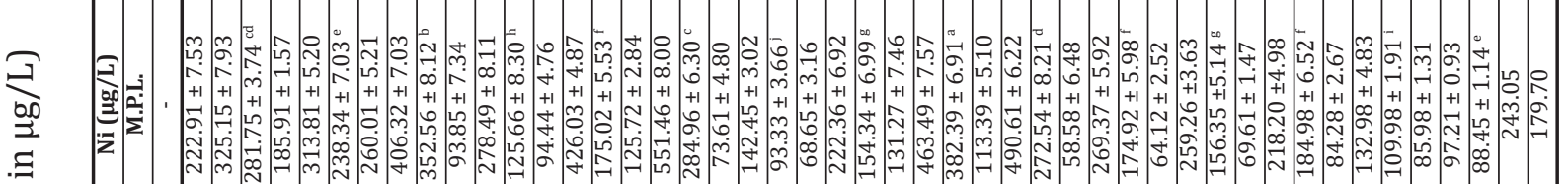

\section{ఏ్} ర్ 萡 苟 $\stackrel{+}{\pi}$


更

E. - A 烈

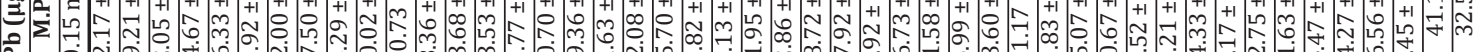

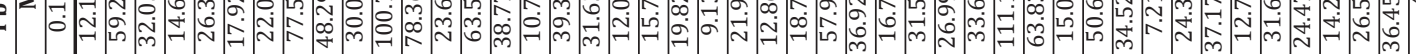
11

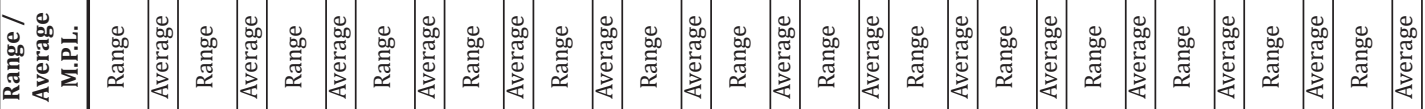
m

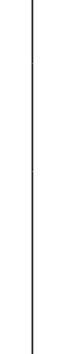

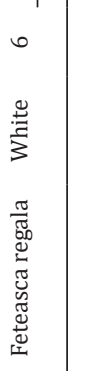



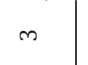

$$
\text { 要 }
$$

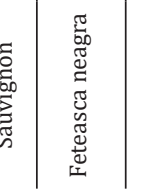

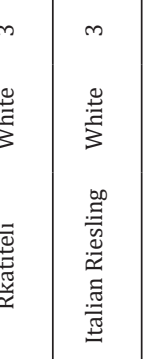

+

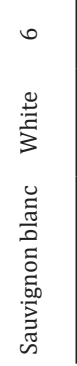

$\mid$

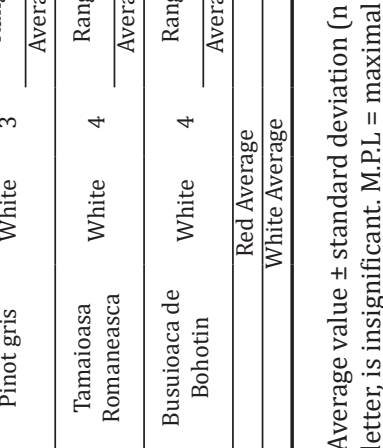




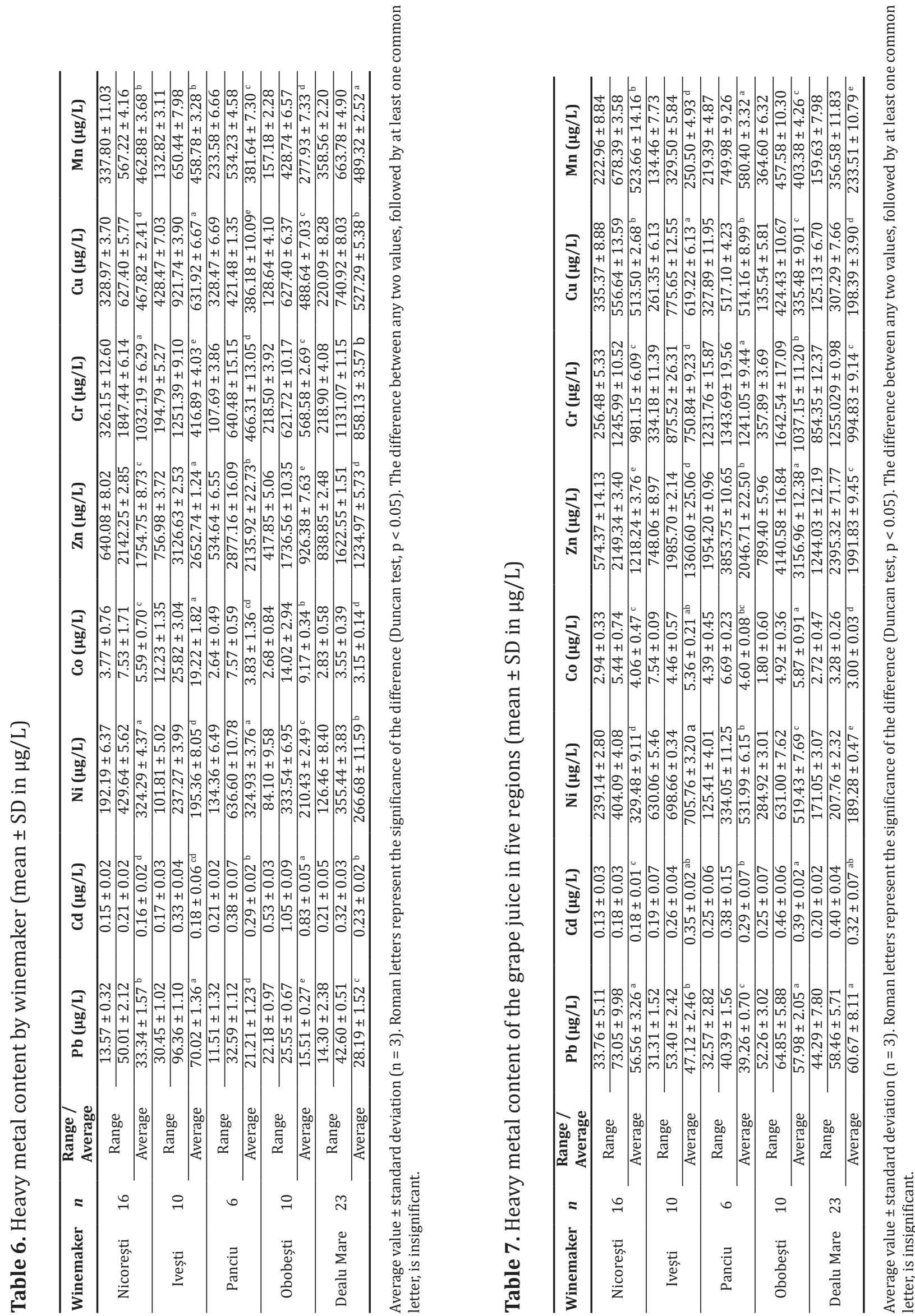


much lower than the upper limit values given by the by International Organization of Vine and Wine of $0.15 \mathrm{mg} / \mathrm{L}$ (O.I.V., 2016). Early studies in England have reported $\mathrm{Pb}$ concentration as high as $1840 \mu \mathrm{g} / \mathrm{L}$ resulting from lead cauldrons (Sherlock et al., 1986). As stainless-steel boilers are used presently this problem seems to have been resolved.

To better understand the obtained results, concerning the distribution of these elements in wine they have been compared with previous studies. In terms of the results presented by Fiket et al. (2001) the concentration of Cd in Croatian wines ranges from 0.175 to $1.88 \mu \mathrm{g} / \mathrm{L}$, and in Bohemian wines $\mathrm{Cr}, \mathrm{Ni}$ and $\mathrm{Pb}$ levels ranges from 18.0-32.0 $\mu \mathrm{g} / \mathrm{L}, 15.0-53.0 \mu \mathrm{g} / \mathrm{L}$ to $11.0-48.0 \mu \mathrm{g} / \mathrm{L}$, respectively according to the results presented by Sperkova and Suchanek, (2005). Marengo and Aceato (2003) who studied wine samples from Nebbiolo area, assert that the levels of concentration of $\mathrm{Cr}$ in this wine area range from 20.0 to $50.0 \mu \mathrm{g} / \mathrm{L}$. In the research done by Gremaud et al. (2004) there were determined elements such as $\mathrm{Mn}$ and $\mathrm{Zn}$ and their concentration ranged from 270 to $600 \mu \mathrm{g} / \mathrm{L}$ and 340 to $1140 \mu \mathrm{g} / \mathrm{L}$, respectively. In terms of wines obtained in Romania these were analyzed by Geana et al. (2013) who analyzed Mn, $\mathrm{Cu}, \mathrm{Co}$, and $\mathrm{Zn}$, the average concentration of $\mathrm{Mn}$, $\mathrm{Co}, \mathrm{Cu}$ and $\mathrm{Zn}$ were $806 \mu \mathrm{g} / \mathrm{L}, 4.35 \mu \mathrm{g} / \mathrm{L}, 501 \mu \mathrm{g} / \mathrm{L}$ and $434 \mu \mathrm{g} / \mathrm{L}$ respectively.

Regarding the results obtained for $\mathrm{Cd}$ and $\mathrm{Co}$, these are comparable with other researches, but the concentration levels of $\mathrm{Mn}$ from the analyzed samples in most studies were lower than in this study.

Alkiș et al. (2014) investigated wine samples that were obtained in Turkey focusing on determination of $\mathrm{Mn}, \mathrm{Co}, \mathrm{Cu}$ and $\mathrm{Zn}$ and the concentration for Mn was (average $399 \mu \mathrm{g} / \mathrm{L}$ ), Co (average $3.37 \mu \mathrm{g} / \mathrm{L}$ ), $\mathrm{Cu}$ (average $145 \mu \mathrm{g} / \mathrm{L}$ ) and $\mathrm{Zn}$ (average $1244 \mu \mathrm{g} / \mathrm{L}$ ) respectively. The highest level of concentration for $\mathrm{Pb}$ in this research was $78.36 \mu \mathrm{g} / \mathrm{L}$, which is lower than the O.I.V. limit (150 $\mu \mathrm{g} / \mathrm{L})$ (O.I.V., 2016) lead content in wine, in addition, the O.I.V. issued the highest levels on $\mathrm{Cu}(1000 \mu \mathrm{g} / \mathrm{L})$ and $\mathrm{Cd}(10 \mu \mathrm{g} / \mathrm{L})$ in wine, the highest $\mathrm{Cu}$ concentration $(921.74 \mu \mathrm{g} / \mathrm{L})$ and $\mathrm{Cd}$ concentration $(0.83 \mu \mathrm{g} / \mathrm{L})$ in this study was lower than this restrictive limit. Similarly, the highest levels of concentration for Zn $(3126.63 \mu \mathrm{g} / \mathrm{L})$ in all the wines were far less than the O.I.V. limit of $\mathrm{Zn}$ (5000 $\mu \mathrm{g} / \mathrm{L})$.

The composition of elements (metals in particular) in wine during fermentation is not stable. During fermentation, the concentration of some metals is lower than that in grapes and must be due to the precipitation with tartrate (e.g. Ca and $\mathrm{K}$ ) or other insoluble precipitation (e.g. $\mathrm{Al}, \mathrm{Cu}$, $\mathrm{Fe}, \mathrm{Mn})$. These changes can be accentuated by the changes in $\mathrm{pH}$ due to alcohol production (Pohl, 2007). During classification and storage to stabilize and conserve wine, metal content also decreases, the magnitude of the decrease depending on the harvest, grape quality and alcohol content, which normally increases with decreasing solubility of salts (Hernández et al., 1996).

At clarification, metals are eliminated with sediments of proteins and sulphated amino acids. During storage, they are precipitated as sulfides (e.g. $\mathrm{Cu}$ ) in reaction with $\mathrm{H}_{2} \mathrm{~S}$ originating from free $\mathrm{SO}_{2}$ (Rodríguez-Mozaz et al., 1999). A significant part of $\mathrm{Cu}, \mathrm{Fe}, \mathrm{Mn}$, and $\mathrm{Zn}$ is removed by adding $\mathrm{K}_{4} \mathrm{Fe}(\mathrm{CN})_{6}$ and precipitating the respective ferrocyanides to prevent wine from being susceptible to browning and formation of metal cloudiness (Benítez et al., 2002).

The concentration of heavy metals in grape juice samples decreases in the order $\mathrm{Zn}>\mathrm{Cr}>\mathrm{Mn}$ $>\mathrm{Cu}>\mathrm{Ni}>\mathrm{Pb}>\mathrm{Co}>\mathrm{Cd}$ for the majority of wine grape cultivars studied.

The distribution of element content in juice samples from Nicorești and Dealu Mare is similar, while in the remaining vineyards the difference is made by $\mathrm{Cu}, \mathrm{Mn}$, and $\mathrm{Ni}$ concentration. $\mathrm{Pb}$ records the highest concentration in Nicoresti (56.56 $\mu \mathrm{g} / \mathrm{L})$ and Dealu Mare (60.67 $\mu \mathrm{g} / \mathrm{L})$ vineyard. Ivesti vineyard records high concentration of $\mathrm{Ni}$ $(705.76 \mu \mathrm{g} / \mathrm{L})$ and $\mathrm{Cu}(619 \mu \mathrm{g} / \mathrm{L})$, while the Panciu and Odobesti vineyards record the highest values (1241.05 $\mu \mathrm{g} \mathrm{Cr} / \mathrm{L}),(580.40 \mu \mathrm{g} \mathrm{Mn} / \mathrm{L})$ in the Panciu vineyard (5.87 $\mu \mathrm{g} \mathrm{Co} / \mathrm{L}),(3156.96 \mu \mathrm{gn} / \mathrm{L})$ in Odobești vineyard respectively.

To evaluate the potential hazards that may arise from the long-term consumption of wine containing these elements, we referenced the concept of an estimated daily intake (EDI). In the researches done by Towle et al. (2017) in order to evaluate the potential hazards from long-term daily consumption of wine uses $195 \mathrm{~mL}$ daily drinking volume, while Zhi-Hao et al. (2019) for evaluation the estimated daily intake of elements 
from wine used a daily drinking volume of 200 $\mathrm{mL}$. For results to be applied to as many people as possible we selected $60 \mathrm{~kg}$ as the adult drinker average weight for calculation of estimated daily intake (EDI). For this, we divided the measured concentration levels of each element into two parts for evaluating: the used average concentration level (average) represented the general intake, and the 95\% confidence interval upper limit (P95) of the average concentration level represented the possible highest intake. The average values for EDI of $\mathrm{Pb}, \mathrm{Cd}, \mathrm{Ni}, \mathrm{Co}, \mathrm{Zn}, \mathrm{Cr}, \mathrm{Cu}$ and $\mathrm{Mn}$ for all wines were $0.111,0.001,0.821,0.027,5.803,2.228$, 1.668 and $1.380 \mu \mathrm{g} / \mathrm{kg}$ bw/day, respectively (Tab. 8 and 9). Thus, there were no adequate toxicity studies accessible to provide a foundation for the

Table 8. Estimated daily intake (EDI, $\mu \mathrm{g} / \mathrm{kg}$ bw/day) of each element through the consumption of wine from five wine-growing areas

\begin{tabular}{|c|c|c|c|c|c|c|c|c|c|}
\hline \multicolumn{2}{|c|}{ Vineyard } & $\mathbf{P b}$ & $\overline{P 95}$ & Cd & $\overline{P 95}$ & $\overline{\mathrm{Ni}}$ & $\overline{P 95}$ & Co & P95 \\
\hline \multirow{3}{*}{ Nicorești } & \multirow{2}{*}{ Range } & 0.046 & 0.053 & 0.001 & 0.001 & 0.643 & 0.657 & 0.013 & 0.034 \\
\hline & & 0.167 & 0.179 & 0.001 & 0.001 & 1.432 & 1.440 & 0.025 & 0.037 \\
\hline & Average & 0.111 & 0.132 & 0.001 & 0.001 & 1.081 & 1.093 & 0.019 & 0.028 \\
\hline \multirow{3}{*}{ Ivești } & \multirow{2}{*}{ Range } & 0.102 & 0.119 & 0.001 & 0.001 & 0.339 & 0.351 & 0.041 & 0.076 \\
\hline & & 0.321 & 0.336 & 0.001 & 0.001 & 0.791 & 0.834 & 0.086 & 0.102 \\
\hline & Average & 0.233 & 0.238 & 0.001 & 0.001 & 0.651 & 0.689 & 0.064 & 0.088 \\
\hline \multirow{3}{*}{ Panciu } & \multirow{2}{*}{ Range } & 0.038 & 0.044 & 0.001 & 0.001 & 0.448 & 0.489 & 0.009 & 0.012 \\
\hline & & 0.109 & 0.118 & 0.001 & 0.001 & 2.122 & 2.345 & 0.025 & 0.034 \\
\hline & Average & 0.071 & 0.089 & 0.001 & 0.001 & 1.083 & 1.121 & 0.013 & 0.023 \\
\hline \multirow{3}{*}{ Odobești } & \multirow{2}{*}{ Range } & 0.074 & 0.083 & 0.002 & 0.002 & 0.280 & 0.298 & 0.009 & 0.016 \\
\hline & & 0.085 & 0.097 & 0.004 & 0.005 & 1.112 & 1.176 & 0.047 & 0.062 \\
\hline & Average & 0.052 & 0.071 & 0.003 & 0.004 & 0.701 & 0.798 & 0.031 & 0.044 \\
\hline \multirow{4}{*}{ Dealu mare } & \multirow{2}{*}{ Range } & 0.048 & 0.056 & 0.001 & 0.001 & 0.422 & 0.469 & 0.009 & 0.016 \\
\hline & & 0.142 & 0.152 & 0.001 & 0.001 & 1.185 & 1.199 & 0.012 & 0.029 \\
\hline & Average & 0.094 & 0.103 & 0.001 & 0.001 & 0.889 & 0.925 & 0.011 & 0.035 \\
\hline & PTDI & & & & & & & & \\
\hline
\end{tabular}

${ }^{1}$ The PTDI ( $\mu \mathrm{g} / \mathrm{kg} / \mathrm{day}$ ) of Cd was calculated from provisional tolerable monthly intake (PTMI) of $25.00 \mu \mathrm{g} /$ body weight based on a month of 30 days (Zhi-Hao et al., 2019).

Table 9. Estimated daily intake (EDI, $\mu \mathrm{g} / \mathrm{kg}$ bw/day) of each element through the consumption of wine from five wine-growing areas

\begin{tabular}{|c|c|c|c|c|c|c|c|c|c|}
\hline \multicolumn{2}{|c|}{ Vineyard } & $\mathbf{Z n}$ & P95 & $\mathrm{Cr}$ & P95 & $\mathbf{C u}$ & P95 & Mn & $\mathbf{P 9 5}$ \\
\hline \multirow{3}{*}{ Nicorești } & \multirow{2}{*}{ Range } & 2.134 & 2.456 & 1.087 & 1.701 & 1.097 & 1.345 & 1.126 & 1.561 \\
\hline & & 7.141 & 8.701 & 6.158 & 7.246 & 2.091 & 3.451 & 1.891 & 2.318 \\
\hline & Average & 5.849 & 6.893 & 3.441 & 4.809 & 1.559 & 1.809 & 1.543 & 1.943 \\
\hline \multirow{3}{*}{ Ivești } & \multirow{2}{*}{ Range } & 2.523 & 2.934 & 0.649 & 0.789 & 1.428 & 1.788 & 0.443 & 0.546 \\
\hline & & 10.422 & 13.101 & 4.171 & 5.998 & 3.072 & 4.745 & 2.168 & 3.312 \\
\hline & Average & 8.842 & 9.990 & 1.390 & 1.563 & 2.106 & 2.610 & 1.529 & 1.980 \\
\hline \multirow{3}{*}{ Panciu } & \multirow{2}{*}{ Range } & 1.782 & 1.928 & 0.359 & 0.387 & 1.095 & 1.339 & 0.779 & 0.865 \\
\hline & & 9.591 & 10.897 & 2.135 & 2.786 & 1.405 & 1.682 & 1.781 & 1.971 \\
\hline & Average & 7.120 & 9.728 & 1.554 & 1.887 & 1.287 & 1.410 & 1.272 & 1.436 \\
\hline \multirow{3}{*}{ Odobești } & \multirow{2}{*}{ Range } & 1.393 & 1523 & 0.728 & 0.899 & 0.429 & 0.487 & 0.524 & 0.643 \\
\hline & & 5.789 & 6.909 & 2.072 & 2.245 & 2.091 & 2.503 & 1.429 & 1.897 \\
\hline & Average & 3.088 & 3.451 & 1.895 & 2.556 & 1.629 & 1.908 & 0.926 & 1.321 \\
\hline \multirow{4}{*}{ Dealu mare } & \multirow[b]{2}{*}{ Range } & 2.796 & 2.997 & 0.730 & 0.823 & 0.734 & 0.612 & 1.195 & 1.213 \\
\hline & & 5.409 & 5.769 & 3.770 & 4.351 & 2.470 & 2.761 & 2.213 & 2.561 \\
\hline & Average & 4.117 & 4.367 & 2.860 & 3.304 & 1.758 & 1.887 & 1.631 & 1.893 \\
\hline & PTDI & \multicolumn{2}{|c|}{1000.00} & \multicolumn{2}{|l|}{ 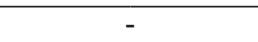 } & \multicolumn{2}{|c|}{1500.00} & \multicolumn{2}{|c|}{${ }^{2} 183.00$} \\
\hline
\end{tabular}

${ }^{1}$ The PTDI ( $\mu \mathrm{g} / \mathrm{kg} / \mathrm{day}$ ) of Cu was calculated from provisional tolerable weekly intake (PTMI) of $3500 \mu \mathrm{g} / \mathrm{body}$ weight. ${ }^{2} \mathrm{The}$ PTDI ( $\mu \mathrm{g} / \mathrm{kg} / \mathrm{day}$ ) of Mn was calculated from a tolerable daily intake of $11.0 \mu \mathrm{g} /$ body weight by $60 \mathrm{~kg}$ adult (Zhi-Hao et al., 2019). 
Table 10. Target hazard quotient (THQ) of trace elements from wines of different wine-growing areas

\begin{tabular}{|c|c|c|c|c|c|c|c|c|c|}
\hline \multicolumn{2}{|c|}{ Vineyard } & $\mathrm{Pb}$ & P95 & $\mathrm{Cd}$ & P95 & $\mathrm{Ni}$ & P95 & Co & $\overline{\mathrm{P} 95}$ \\
\hline \multirow{3}{*}{ Nicorești } & \multirow{2}{*}{ Range } & 0.013 & 0.017 & 0.001 & 0.001 & 0.032 & 0.057 & 0.033 & 0.054 \\
\hline & & 0.048 & 0.069 & 0.001 & 0.001 & 0.072 & 0.098 & 0.100 & 0.231 \\
\hline & Average & 0.032 & 0.046 & 0.001 & 0.001 & 0.054 & 0.065 & 0.067 & 0.089 \\
\hline \multirow{3}{*}{ Ivești } & \multirow{2}{*}{ Range } & 0.029 & 0.034 & 0.001 & 0.001 & 0.017 & 0.026 & 0.133 & 0.156 \\
\hline & & 0.092 & 0.106 & 0.001 & 0.001 & 0.040 & 0.063 & 0.300 & 0.467 \\
\hline & Average & 0.067 & 0.079 & 0.001 & 0.001 & 0.033 & 0.045 & 0.200 & 0.309 \\
\hline \multirow{3}{*}{ Panciu } & \multirow{2}{*}{ Range } & 0.011 & 0.014 & 0.001 & 0.001 & 0.023 & 0.039 & 0.033 & 0.058 \\
\hline & & 0.031 & 0.039 & 0.001 & 0.001 & 0.106 & 0.136 & 0.100 & 0.147 \\
\hline & Average & 0.020 & 0.031 & 0.001 & 0.001 & 0.054 & 0.075 & 0.033 & 0.053 \\
\hline \multirow{3}{*}{ Odobești } & \multirow{2}{*}{ Range } & 0.021 & 0.027 & 0.002 & 0.003 & 0.014 & 0.028 & 0.033 & 0.049 \\
\hline & & 0.024 & 0.042 & 0.004 & 0.006 & 0.056 & 0.080 & 0.167 & 0.198 \\
\hline & Average & 0.015 & 0.026 & 0.003 & 0.005 & 0.035 & 0.049 & 0.100 & 0.126 \\
\hline \multirow{3}{*}{ Dealu mare } & \multirow{2}{*}{ Range } & 0.014 & 0.018 & 0.001 & 0.001 & 0.021 & 0.034 & 0.033 & 0.043 \\
\hline & & 0.041 & 0.065 & 0.001 & 0.001 & 0.059 & 0.076 & 0.033 & 0.029 \\
\hline & Average & 0.027 & 0.034 & 0.001 & 0.001 & 0.045 & 0.061 & 0.033 & 0.032 \\
\hline Total & & 0.032 & 0.043 & 0.001 & 0.018 & 0.044 & 0.060 & 0.087 & 0.121 \\
\hline
\end{tabular}

Table 11. Target hazard quotient (THQ) of trace elements from wines of different wine-growing areas

\begin{tabular}{|c|c|c|c|c|c|c|c|c|c|}
\hline \multicolumn{2}{|c|}{ Vineyard } & $\mathrm{Zn}$ & P95 & $\mathrm{Cr}$ & P95 & $\mathrm{Cu}$ & P95 & $\mathrm{Mn}$ & P95 \\
\hline \multirow{3}{*}{ Nicorești } & \multirow{2}{*}{ Range } & 0.007 & 0.009 & 0.363 & 0.468 & 0.220 & 0.354 & 0.008 & 0.013 \\
\hline & & 0.024 & 0.033 & 2.053 & 3.756 & 0.418 & 0.689 & 0.014 & 0.019 \\
\hline & Average & 0.020 & 0.028 & 1.147 & 2.698 & 0.312 & 0.451 & 0.011 & 0.013 \\
\hline \multirow{3}{*}{ Ivești } & \multirow{2}{*}{ Range } & 0.008 & 0.015 & 0.217 & 0.365 & 0.286 & 0.356 & 0.003 & 0.005 \\
\hline & & 0.035 & 0.053 & 1.390 & 1.764 & 0.614 & 0.896 & 0.016 & 0.023 \\
\hline & Average & 0.029 & 0.033 & 0.463 & 0.687 & 0.422 & 0.577 & 0.011 & 0.026 \\
\hline \multirow{3}{*}{ Panciu } & \multirow{2}{*}{ Range } & 0.006 & 0.009 & 0.120 & 0.187 & 0.218 & 0.365 & 0.006 & 0.009 \\
\hline & & 0.032 & 0.045 & 0.710 & 0.865 & 0.280 & 0.290 & 0.013 & 0.019 \\
\hline & Average & 0.024 & 0.036 & 0.517 & 0.780 & 0.258 & 0.298 & 0.009 & 0.015 \\
\hline \multirow{3}{*}{ Odobești } & \multirow{2}{*}{ Range } & 0.005 & 0.007 & 0.243 & 0.321 & 0.086 & 0.099 & 0.004 & 0.006 \\
\hline & & 0.019 & 0.023 & 0.690 & 0.875 & 0.418 & 0.789 & 0.010 & 0.013 \\
\hline & Average & 0.010 & 0.015 & 0.633 & 0.874 & 0.326 & 0.376 & 0.007 & 0.008 \\
\hline \multirow{3}{*}{ Dealu mare } & \multirow{2}{*}{ Range } & 0.009 & 0.013 & 0.243 & 0.341 & 0.146 & 0.187 & 0.009 & 0.012 \\
\hline & & 0.018 & 0.023 & 1.257 & 1.632 & 0.494 & 0.785 & 0.016 & 0.023 \\
\hline & Average & 0.014 & 0.016 & 0.953 & 1.435 & 0.352 & 0.477 & 0.012 & 0.014 \\
\hline Total & & 0.019 & 0.026 & 0.743 & 1.295 & 0.334 & 0.436 & 0.010 & 0.015 \\
\hline
\end{tabular}

observed rate of adverse effect (NOAEL). Based on a 60-kilogram adult person and moderate consumption of 200 milliliters of wine/day, the estimated daily intake of these inorganic components from wines was well below the daily allowance. The target hazard quotient suggests that the exposed humans would not experience significant health risks when ingesting these individual elements from daily consumption of 200 milliliters of Romanian wines/day.

The THQ was the ratio of the estimated dose of elements from wines to a corresponding reference dose, and this approach offered an indication of the risk level due to reference doses of $\mathrm{Pb}, \mathrm{Cd}, \mathrm{Ni}$,
Co, $\mathrm{Zn}, \mathrm{Cr}, \mathrm{Cu}$, and Mn which were 3.50, 1.00, 20.00, $0.30,300.00,3.00,5.00$ and $140,00 \mu \mathrm{g} / \mathrm{kg}$ bw/day, respectively. An exception is made by the Nicorești vineyard, which in the case of $\mathrm{Cr}$ records light values above 1 (average 1.147), the higher THQ values showed a slightly potential of exposed risk. The THQ values of each estimated element did not exceed 1 in all areas, suggesting that the exposed population would not experience significant health risks when ingesting these individual elements from daily consumption of $200 \mathrm{~mL}$ of Romanian wines. The total THQ values used to estimate the cumulative health risk effect were calculated by the sum of the THQ values of these elements, 
commonly referred to as HI. In Tables 10 and 11, the HI values of different wine areas were also less than 1 , and the highest $\mathrm{HI}$ values were 0.743 and 1.295 (P95). It showed that these elements did not cause health problems to people through the daily consumption of $200 \mathrm{~mL}$ of Romanian wine, but the risks that might be presented were higher in the case of $\mathrm{Cr}$ level concentration. The THQ values of $\mathrm{Cr}$ accounted for the highest average proportions of the total THQ values $47 \%$, and also the average of contribution proportions of $\mathrm{Cu}$ and $\mathrm{Mn}$ of the total THQ values 21\% ranked second. In this research the THQ also represented the contribution of wine to contaminants in the acceptable range for daily diet, the average THQ of Cr was 0.743 , which meant that the contribution of wine consumption to the tolerable daily intake of $\mathrm{Cr}$ was $74.3 \%$. Risk assessment for a specific contaminant intake comprehensive consideration of all intake mechanisms, and wine consumption was just one such path, the amount of wine consumption was, therefore, more important for health risk assessment of wine in the daily diet of drinkers.

\section{Conclusion}

The concentration of $\mathrm{Pb}, \mathrm{Cd}, \mathrm{Ni}, \mathrm{Co}, \mathrm{Zn}, \mathrm{Cr}$, $\mathrm{Cu}$ and $\mathrm{Mn}$ in 321 wine and grape juice samples sourced from the five main Romanian wineproducing regions was determined. The results from this research suggested that the levels of concentration elements in red wines decreased in the order of $\mathrm{Zn}>\mathrm{Mn}>\mathrm{Cr}>\mathrm{Cu}>\mathrm{Ni}>\mathrm{Pb}>\mathrm{Co}$ $>\mathrm{Cd}$, and in white wines decreased in the order of $\mathrm{Zn}>\mathrm{Mn}>\mathrm{Cu}>\mathrm{Cr}>\mathrm{Ni}>\mathrm{Pb}>\mathrm{Co}>\mathrm{Cd}$. The Ivești and Nicorești vineyard-areas had a higher concentration level in $\mathrm{Pb}$ than the other studied vineyard-areas. The measured concentration levels of $\mathrm{Cd}$ showed that all vineyard-areas had the same levels except Odobești area, which records high concentration in $\mathrm{Cd}$. The $\mathrm{Ni}$ concentration was higher in the Nicorești and Panciu vineyards, $\mathrm{Co}, \mathrm{Zn}$ and $\mathrm{Cu}$ in Ivești vineyard, $\mathrm{Cr}$ and $\mathrm{Mn}$ in the Nicorești and Dealu Mare respectively.

The daily estimated intake of these elements potentially hazardous to health for wine consumers, assuming a daily wine consumption of $200 \mathrm{~mL}$ wine for $60 \mathrm{~kg}$ drinkers, was much lower than the daily tolerable intake for this character.

The THQ values of each element did not exceed the value of 1 for all the studied areas, which means that the population that consumes $200 \mathrm{~mL}$ of Romanian wine ever day not exposed to any risk, an exception is made by the wine obtained in Nicorești vineyard in case of $\mathrm{Cr}$ the value obtained is a slight value above 1 (average 1.147), which indicates a slight probability of exposed risk. The HI showed that consuming 200 $\mathrm{mL}$ daily of wine does not pose a threat to the tolerable daily intake of potential risk elements in the daily diet. High values for $\mathrm{Cr}, \mathrm{Cu}$, and $\mathrm{Mn}$ were obtained regarding THQ which meant that were major contaminants and needed more attention to them. On the other side, the wine consumption in the daily diet of drinkers was more important for comprehensive health risk assessment due to the presence of other intake pathways. Therefore, the cumulative impact of wine consumption on trace elements intake in the daily drinkers should not be ignored in the future.

Acknowledgments. This project is funded by the Ministry of Research and Innovation through Program 1 - Development of the National Research and Development System, Subprogram 1.2 - Institutional Performance - Projects for Financing the Excellence in CDI, Contract no. 37PFE/06.11.2018. Title of the project: "Increasing the institutional performance through consolidation and development of research directions within the USAMVCN".

\section{References}

1. Alkiș İM, Öz S, Atakol A, Yilmaz N, Anli RE, Atakol O (2014). Investigation of heavy metals concentrations in some Turkish wines. Journal of Food Composition and Analysis, 33: 105-110.

2. Avram V, Voica C, Hosu A, Cimpoiu A, Măruțoiu C (2014). ICP-MS characterization of some Romanian white wines by their mineral content. Revue Romanine de Chimice 59(11-12): 1009-1019.

3. Álvarez M, Moreno IM, Jus ÁM, Cameán AM, González AG (2007). Study of mineral profile of Montilla-Moriles "fino" wines using inductively coupled plasma atomic emission spectrometry methods. Journal of Food Composition and Analysis, 20, 391-395.

4. Bajpai R, Upreti DK, Nayaka S, Kumari B (2010). Biodiversity, bioaccumulation and physiological changes in lichens growing in the vicinity of coal-based thermal power plant of Raebareli district, North India. Journal of Hazardous Materials, 174: 429-436.

5. Benítez P, Castroo R, Sánchez Pazo JA, Barroso CC (2002). Influence of metallic content of fino sherry wine on its susceptibility to browning. Journal of Agricultural and Food Chemistry, 35: 785-791. 
6. Bora FD, Bunea CI, Rusu T, Pop N (2015). Vertical distribution and analysis of micro-, macroelements and heavy metals in the system soil-grapevine-must in vineyard form North-West Romania. Chemistry Central Journal, DOI: 10.1186/s13065-015-0095-2.

7. Bora FD, Donici A, Oșlobanu A, Fițiu A, Babeș AC, Bunea CI (2016). Qualitative assessment of the white wine varieties grown in Dealu Bujorului vineyard, Romania. Notulae Botanicae Horti Agrobotanici 44(2): 593-602.

8. Bora FD, Donici A, Rusu T, Bunea A, Popescu D, Bunea Cl (2018a). Elemental profile and ${ }^{207} \mathrm{~Pb} /{ }^{206} \mathrm{~Pb},{ }^{208} \mathrm{~Pb} /{ }^{206} \mathrm{~Pb}$, ${ }^{204} \mathrm{~Pb} /{ }^{206} \mathrm{~Pb},{ }^{87} \mathrm{Sr} /{ }^{86} \mathrm{Sr}$ isotope ratio as fingerprints for geographical traceability of Romanian wines. Notulae Botanicae Horti Agrobotanici Cluj-Napoca, 46(1): 223239.

9. Bora FD, Donici A, Calugar A, Somsai P, Clapa D, Gal E, Bunea CI, Dumitraș A (2018b). Elemental content and lead-strontium isotope characterization of wine. Studia UBB Chemia, 63(1): 137-155.

10. Cvetković J, Arpadjan S, Karadjova I, Stafilov T (2006). Determination of cadmium in wine by electrothermal atomic absorption spectrometry. Acta Pharmaceutica 56: $227,69-78$.

11. Dinca OR, Ionete RE, Costinel D, Geana IE, Popescu R, Stefanescu I, Radu GL (2016). Regional and vintage discrimination of Romanian wines based on elemental and isotopic fingerprinting. Food Analytical Methods, 9(8): 2406-2417.

12. Dehelean A, Voica C (2012). Determination of lead and strontium isopote rations in wines by inductively coupled plasma mass spectrometry. Romanian Journal of Physics, 57 (7-8): 1194-1203.

13. Dragovic S, Cuzic M, Beskoski LS, Gajic C, Bajat B, Kilibarba M (2013). Trace element distribution in surface soils from a coal burning power production area. Catena 104: 288296.

14. Elci L, Arslan Z, Tyson JF (2009). Determination of lead in wine and rum samples by flow injection-hydride generation-atomic absorption spectrometry. Journal of Hazardous Materials, 162: 880-885.

15. Fabani MP, Arrúa RC, Vázquez F, Diaz MP, Baronin MV, Wunderlin DA (2010). Evaluate of elemental profile coupled to chemometrics to assessment the geographical origin of Argentinean wines. Food Chemistry, 119: 372379.

16. FAO/WHO (1982). Evaluation of certain food additives and contaminants, the twenty-sixth of the joint FAO/ WHO Expert Committee on Food Additives, World Health Organization. Geneva, Switzerland.

17. FAO/WHO (2007). Evaluation of certain food additives and contaminants, the twenty-sixth of the joint FAO/ WHO Expert Committee on Food Additives, World Health Organization. Geneva, Switzerland.

18. FAO (2011). Safety evaluation of certain contaminants in food. JEFCA Report Monographs 8. http://www.fao. org/3/a-at881e.pdf Accessed 17.04.19.

19. FAO/WHO (2011). Evaluation of certain food additives and contaminants, seventy-third report of the Joint FAO/
WHO Expert Committee of Food Additives; World Health Organization, Geneva, Switzerland.

20. Fang Y, Sun XY, Yang WJ, Ma N, Xin ZH, Fu J, Liu XC, Liu M, Marinnga AM, Zhu XF, Hu QH (2014). Concentration and health risks of lead, cadmium, arsenic, and mercury in rice and edible mushrooms in China. Food Chemistry 147: 147-151.

21. Forti E, Salovaara S, Cetin Y, Bulgheroni A, Tessadri R, Jennings P, Pfaller W, Prieto P (2011). In vitro evaluation of the toxicity induced by nickel and particulate forms in human airway epithelial cells. Toxicology in Vitro, 25: 454-461.

22. Filket Ž, Mikac N, Kiewald G (2011). Arsenic and other trace elements in wines of eastern Croatia. Food Chemistry, 126(3): 941-947.

23. Galani-Nikolakaki S, Nallithrakas-Kontos N, Katsanos AA (2002). Trace element analysis of Cretan wines and wine products. Science of the Total Environment, 285: 155163.

24. Geana I, Iordache A, Ionete R, Marinescu A, Ranca A, Culcea M (2013). Geographical origin identification of Romanian wines by ICP-MS elemental analysis. Food Chemistry 13(2-3): 1125-1134.

25. Geana EI, Sandru C, Staciu V, Ionete R (2016). Elemental profile and ${ }^{87} \mathrm{Sr} /{ }^{86} \mathrm{Sr}$ isotope ratio as fingerprints for geographical traceability of wines: an approach on Romanian wines. Food Analytical Methods, 10(1): 63-73.

26. Goldberg DM, Bromberg IL (1996). Health effects of moderate alcohol consumption: A paradigmatic risk factor. Clinica Chimica Acta, 246(1-2): 1-3.

27. Goldberg IJ, Mosca L, Piano MR, Fisher EA (2001). Wine and your heart: a science advisory for healthcare professionals from the Nutritional Committee, Council on Epidemiology and Prevention, and Council on Cardiovascular Nursing of the American Heart Association. Circulation, 103: 472475.

28. Gremaud G, Quaile S, Piantini U, Pfammatter E, Corvi C (2004). Characterization of Swiss vineyards using isotopic data in combination with trace elements and classical parameters. European Food Reseach and Technology, 219: 97-104.

29. Greenough JD, Mallory-Greenough LM, Fryer BJ (2005). Geology and wine: Regional trace element fingerprinting of Canadian wines. Geoscience Canada, 32: 129-138.

30. Guardia M, Garrigues S (2015). Handbook of mineral elements in food. 1th ed.). New York: John Wiley \& Sons (Chapter 20).

31. Hernández GG, Hardisson de la Torre A, Arias León JJ (1996). Quantity of K, Ca, Na, Fe, Cu, Pb, Zn and ashes in DOC Tacoronte-Acentejo (Canary Islands, Spain) musts and wines. Zeitschrift für Lebensmittel-Untersuchung und Forschung, 203(6): 517-521.

32. Interesse FS, Lamparelli F, Alloggio V (1994). Mineral contents of some southern Italian wines. Zeitschrift für Lebensmittel-Untersuchung und-Forschung, 178: 272278.

33. Ivanova-Petropulos V, Balabanova B, Mitrev S, Nedelkovski D, Dimovska V, Gulaboski R (2016). Optimization and 
validation of a microwave digestion method for multielement characterization of Vranec wines. Food Analytical Methods 9(1): 48-60.

34. Kabata-Pendias A, Pendias H (1984). Trace elements in soils and plants. (3rd ed.) Boca Raton: CRC Press (Chapter 13).

35. Kallithraka S, Arvanitoyannis IS, Kefalas PA, Zajouli E, Soufleros E, Psarra E (2001). Instrumental and sensory analysis of Greek. Food Chemistry, 73: 501-514.

36. Kment P, Mihaljević M, Ettler V, Šebek O, Strnad L, Rohlavá L (2005). Differentiation of Czech wines using multielement composition - A comparison with vineyard soil. Food Chemistry, 91(1): 157-165.

37. Kostić D, Mitić S, Miletić G, Despotović S, Zarubica A (2010). The concentration of $\mathrm{Fe}, \mathrm{Cu}$, and $\mathrm{Zn}$ in selected wines from South-East Serbia. Journal of the Serbian Chemical Society, 75: 1701-1709.

38. Koreňovská M, Suhaj M (2005). Identification of some Slovakian and European wines by the use of factor analysis of elemental data. European Food Research and Technology, 221: 550-558.

39. Kunkee RE, Eschnauer HR (2003). Wine. (6th ed.). Weinheim: Wiley-VCH, (Chapter 2).

40. Lara R, Cerutti S, Salonia JA, Olsina RA, Martínez LD (2005). Trace element determination of Argentine wine using ETAAS and USN-ICP-OES. Food and Chemical Toxicology, 43: 293-297.

41. Marengo E, Aceto M (2003). Statistical investigation of the differences in the distribution of metals in Nebbiolobased wines. Food Chemistry, 81: 621-630.

42. Martin MA, Goya L, Ramos S (2017). Protective effects of tea, red wine, and cocoa in diabetes. Evidence from human studies. Food Chemistry and Toxicology, 109: 302-314.

43. Meeker JD, Rossano MG, Protas B, Diamond MP, Puscheck E, Daly D, Paneth N, Wirth JJ (2008). Cadmium, lead, and other metals in relation to semen quality. Human evidence for molybdenum as a male reproductive toxicant. Environmental Health Perspectives, 116: 1473-1479.

44. Monasterio RP, Wuilloud RG (2009). Trace level determination of cadmium in wine by on-line preconcentration in a 5-Br-PADAP functionalized woolpacked microcolumn coupled to flame atomic absorption spectrometry. Talanta, 79: 1484-1488.

45. Needleman HL (2004). Lead poisoning. Annual Review of Medicine, 55: 209-222.

46. O.I.V. (2016). Maximum acceptable limits of various substances contained in wine. In Compendium of international methods of analysis of wine and must analysis. Paris, France.
47. Preedy VR, Watson R (2003). Reviews in food and nutrition toxicity. (1th ed.). New York: Taylor \& Francis (Chapter 9).

48. Pyrzyńska K (2007). Chemical speciation and fractionation origin of Argentinean wines. Chemical Speciation and Bioavailability, 19(1): 1-8.

49. Pohl P (2007). What do metals tell us about wine? Trends in Analytical Chemistry, 26: 941-949.

50. Płotka-Wasylka J, Frankowski M, Simeonov V, Polkowska Ż, Namieśik J (2018). Determination of metals content in wine samples by inductively coupled plasma-mass spectrometry. Molecules, 23(11): 2886-2897.

51. Rielly C (2002a). Metal contamination of food. (3rd ed.). Blackwell Science Ltd, Oxford (Chapter 1).

52. Rielly C (2002b). Metal contamination of food. (3rd ed.). Blackwell Science Ltd, Oxford (Chapter 4).

53. Rodríguez-Mozaz S, Sotro AC, Garrido JJ, Azpilicueta CA (1999). Influence of decantation of viura must on the cation content. Evolution during wine fermentation and stabilization. Food Research International, 32(10): 683689.

54. Riganakos KA, Veltsistas RG (2003). Comparative spectrophotometric determination of the total iron content in various white and red Greek wines. Food Chemistry, 82: 637-643.

55. Sherlock JC, Pickford CJ, White GF (1986). Lead in alcoholic beverages. Food Additives and Contaminants, 3: 347-354.

56. Sperkova J, Suchanek M (2005). Multivariate classification of wines from different bohemian regions (Czech Republic). Food Chemistry, 93: 659-663.

57. Towe KM, Garnick LM, Monnot AD (2017). A human health risk assessment of lead $(\mathrm{Pb})$ investigation among adult wine consumers. International Journal of Food Contamination, 4: 1-9.

58. Tuzen M (2009). Toxic and essential trace elemental contents in fish species from the Black Sea, Turkey. Food Chemistry and Toxicology, 47: 1785-1790.

59. USEPA (1989). Risk assessment for superfund, volume I. In human Health Evaluation Manual, part A; the United States Environmental Protection Agency Publication: Washington, DC, USA.

60. WHO (2005). Nickel in drinking-water. In background document for development of WHO guidelines for drinking-water quality. World Health Organization, Geneva, Switzerland.

61. Zhi-Hao D, Zhang A, Yang ZW, Ya-Li Z, Jian M, Fei W, Liu YX, Zhang JJ, Fang YL (2019). A human health risk assessment of trace elements present in Chinese wine. Molecules, 24(2): 248-262. 